\title{
The role of the tissue renin-angiotensin system in the response of the rat adrenal to exogenous angiotensin II
}

\author{
G P Vinson, R Teja, M M Ho, J P Hinson and J R Puddefoot \\ Department of Biochemistry, St Bartholomew's and The Royal London School of Medicine and Dentistry, Queen Mary and Westfield College, Mile End Road, \\ London E1 4NS, UK \\ (Requests for offprints should be addressed to G P Vinson) \\ ( $\mathrm{M} \mathrm{M} \mathrm{Ho} \mathrm{is} \mathrm{now} \mathrm{at} \mathrm{Rayne} \mathrm{Institute,} \mathrm{Department} \mathrm{of} \mathrm{Medicine,} \mathrm{University} \mathrm{College} \mathrm{London,} 5$ University St, London WC1 6JJ, UK)
}

\begin{abstract}
The tissue renin-angiotensin systems (RAS) may have specific roles that complement those of the systemic RAS. In the adrenal, the tissue RAS has been implicated in the regulation of glomerulosa tissue growth and function, and in mediating the response of the tissue to stimulation by $\mathrm{ACTH}$ and potassium ions.

To examine the role of the rat adrenal tissue RAS in its response to angiotensin II stimulation, adrenals were incubated either as bisected glands or as separated capsular glands (largely glomerulosa) under control conditions, or in the presence of the angiotensin-converting enzyme inhibitor captopril, or of angiotensin II, or both.

Captopril inhibited the two different tissue preparations in different ways. In the capsular gland it inhibited basal
\end{abstract}

aldosterone output, but facilitated its response to angiotensin II. In the bisected gland, captopril inhibited the response of aldosterone to angiotensin II.

Other data suggest that one way in which captopril functions is by preventing the conversion of fasciculatagenerated 18-hydroxydeoxycorticosterone (18-OH-DOC) to aldosterone in the glomerulosa. Immunolocalisation of $18-\mathrm{OH}-\mathrm{DOC}$ in perfused rat adrenal confirms that one function of angiotensin II is to mobilise tissue-sequestered 18-OH-DOC.

The results illustrate the importance of tissue RAS in the synthesis of aldosterone and the response to angiotensin II.

Journal of Endocrinology (1998) 158, 153-159

\section{Introduction}

The functions of the systemic renin-angiotensin system (RAS), and the generation of angiotensin II, have been widely studied over three decades, and its role in mammalian electrolyte homeostasis and haemodynamics, particularly through the regulation of aldosterone secretion and cardiovascular function, is reasonably well understood (Peach 1977, Ferrario 1990, Jeunemaitre et al. 1992, Vinson et al. 1995a).

More recently, attention has been focused on the tissue RAS, for which there is a now great deal of evidence particularly for the adrenal, gonads, kidney, heart, pituitary and brain (Phillips et al. 1993). This has stimulated interest in the wider range of angiotensin actions, frequently unrelated to its systemic functions, that angiotensin II has in the tissues (Vinson et al. 1995a).

Perhaps the most studied tissue RAS, however, is that of the adrenal gland. Renin and angiotensinogen genes are expressed in the rat adrenal (Dzau et al. 1987), and renin and angiotensin are formed primarily in the zona glomerulosa (Mulrow 1992), where angiotensin-converting enzyme (ACE) is also expressed (Shier et al. 1989, Oda et al. 1991). Both renin mRNA and angiotensin II content are regulated by dietary sodium (Kifor et al. 1991), and the latter also by potassium loading (Nakamaru et al. 1985). The local RAS is thought to have trophic effects on the glomerulosa, and in particular to have a significant role in the regulation of aldosterone synthase (Sander et al. 1994, Vinson 1995). Similar systems exist in human adrenal glands (Wang et al. 1992).

In the case of the adrenal, therefore, the evidence suggests that regulation of tissue RAS and the actions of tissue-generated angiotensin II are apparently similar to those for the systemic RAS system. Clearly this leads to difficulties in interpretation: why have two RAS? Nevertheless, the evidence continues to accumulate that the tissue RAS may have an essential role which supports glomerulosa function in many conditions. For example, aldosterone production by rat adrenal explants in response to potassium ion stimulation was inhibited in the presence of the ACE inhibitor lisinopril (Shier et al. 1989), and in bovine glomerulosa cells the presence of specific angiotensin II type 1 (AT1) receptor antagonists inhibits both basal aldosterone production and the responses to stimulation by potassium ions or corticotrophin (Gupta et al. 1995).

This paper examines the possibility that the tissue RAS has a role in the response of the rat adrenal to exogenously 
added angiotensin II, and relates the findings to new concepts of aldosterone biosynthesis.

\section{Materials and Methods}

\section{Animals}

Adrenal tissue was taken from female Wistar rats, 200$250 \mathrm{~g}$ weight, obtained from commercial suppliers, and maintained briefly at Queen Mary and Westfield College.

\section{Incubations}

In general, rat adrenals were incubated either as halved glands, or after division into capsular (connective tissue, zona glomerulosa and some fasciculata cells) and inner zone fractions (Fattah et al. 1977). Tissues were preincubated at $37{ }^{\circ} \mathrm{C}$, one gland equivalent in $1 \mathrm{ml} \mathrm{Krebs-}$ Ringer bicarbonate (KRBG, $3.6 \mathrm{mmol} \mathrm{K} / 1 ; 0.2 \%(\mathrm{w} / \mathrm{v}$ ) glucose) under an atmosphere of $95 \% \mathrm{O}_{2}$ and $5 \% \mathrm{CO}_{2}$ for $1 \mathrm{~h}$. Captopril when used was added to preincubation media as well as to final incubation media. Preincubation media were then discarded and fresh KRBG $(1 \mathrm{ml})$ was added, with or without the addition of stimulants or blockers, to experimental flasks. The experimental agents used were: angiotensin II (1 and $100 \mathrm{nmol}$; Sigma Chemical Co., Poole, Dorset, UK), captopril (1 $\mu \mathrm{mol} / \mathrm{l}$; Sigma). Tissues were then removed, and incubation media were extracted $(2 \times$ equal volumes of ethyl acetate) for hormone assay, using specific RIA methods as previously described (Vazir et al. 1981, Henville et al. 1989, Vinson et al. 1995b). In particular, it is important to emphasise that the antibody for 18-hydroxydeoxycorticosterone (18OH-DOC) shows less than $0 \cdot 01 \%$ crossreactivity with most steroids, except for aldosterone and 18-hydroxycorticosterone (crossreactivity $\sim 1 \%$ ). Since $18-\mathrm{OH}-$ DOC is stored in adrenal tissue at much higher concentrations than other steroids, and since at least part of the tissue pool is bound to cellular component(s) (Vinson et al. $1991,1995 b)$, it was appropriate to use this antibody in direct (unextracted) assays (by direct addition of antibody and radioactively labelled $18-\mathrm{OH}-\mathrm{DOC}$ to tissue homogenates), and also in immunocytochemical methods for this steroid.

\section{Perfusion fixation and immunocytochemistry}

Rat adrenal glands were perfused in situ as previously described (Hinson et al. 1985, 1988), and then snap frozen in liquid nitrogen after various intervals of perfusion, either under control conditions or after stimulation with a bolus dose of $1 \mathrm{pmol}$ angiotensin II. Frozen sections $(8 \mu \mathrm{m})$ mounted on poly-L-lysine coated glass slides were air dried. Dried sections were fixed in $3 \cdot 7 \%(\mathrm{v} / \mathrm{v})$ formaldehyde in PBS ( $\mathrm{pH} 7 \cdot 4,0.1 \mathrm{~mol} / \mathrm{l})$ for $10 \mathrm{~min}$ at room temperature. Fixed sections were washed in PBS for 10 min with two changes. Non-specific binding was blocked by incubating sections with $1 \%(\mathrm{w} / \mathrm{v})$ blocking reagent (Boehringer Mannheim, Lewes, Sussex, UK) for $10 \mathrm{~min}$. Excess blocking reagent was drained, and sections were then incubated with 18-OH-DOC sheep antiserum (1:1000 dilution) or non-immune sheep serum $(1: 1000$ dilution; DAKO Ltd, High Wycombe, Bucks, UK) as negative control for $30 \mathrm{~min}$. Excess antibody was removed by PBS wash as above. Specific binding was detected by incubating the cell sections with FITC-conjugated antisheep IgG antiserum (1:20 dilution; Sigma) for $30 \mathrm{~min}$. Excess labelled antibody was removed as above. The sections were then mounted with glycerol/PBS and viewed under a light microscope with a fluorescent bulb and a 495 nm filter (Leica UK Ltd, Milton Keynes, Bucks, UK).

\section{Results}

The results shown in Figs 1-3 represent mean values and S.E.M., $n=6$ for each experimental group, and the data for each figure are those from a single experimental series. Each of these were in fact entirely repeated on at least one further occasion, with similar findings.

The data show that inhibition of tissue ACE inhibits aldosterone synthesis in the rat adrenal, and affects its response to exogenous angiotensin II. However, the effects of captopril addition to incubation media were different in detail in the two tissue preparations, and for the different steroids studied.

\section{Aldosterone}

In the bisected gland preparation, aldosterone was significantly increased by the addition of angiotensin II to incubation media under control conditions, though not in the presence of captopril (Fig. 1a). Conversely, in the capsular gland preparation, aldosterone output (generally significantly less than in the whole tissue preparation) was not affected by angiotensin II stimulation under control conditions. However, when captopril was added alone, aldosterone output was significantly depressed, though it was enhanced by the further addition of angiotensin II (Fig. 1b).

\section{8-OH-DOC}

In the bisected gland preparation, like aldosterone, 18$\mathrm{OH}-\mathrm{DOC}$ output was stimulated by angiotensin II under control conditions (Fig. 2a). The addition of captopril gave complex results. In the absence of added angiotensin II, captopril significantly enhanced the release of 18OH-DOC into incubation media, and this was reduced by the addition of a low concentration of 

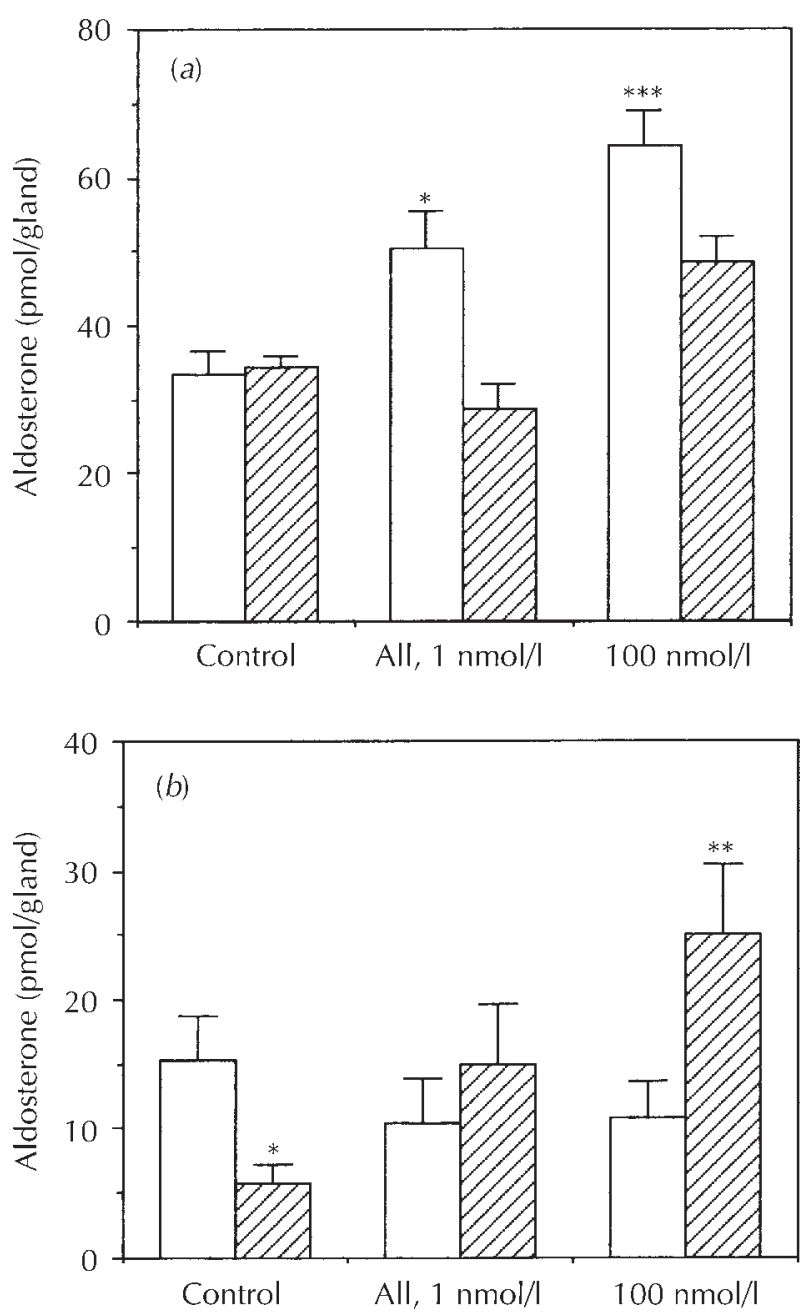

Figure 1 Effects of captopril (shaded bars), in the absence or presence of angiotensin II (AII) at two concentrations, on aldosterone output by bisected rat adrenal glands and isolated adrenal capsular tissue. In bisected glands (a) captopril had no effect on basal aldosterone output but inhibited the response to exogenously added All. Conversely in isolated intact capsules (b) captopril inhibited basal aldosterone output, but facilitated the response to added All. Mean values \pm S.E.M., $n=6$ for each group. ${ }^{*} P<0 \cdot 05,{ }^{*} P<0 \cdot 01,{ }^{*} * * P<0.001$ relative to unstimulated controls in the absence of captopril, by ANOVA and Student's t-test.

angiotensin II. A higher concentration of angiotensin II restored the higher value of $18-\mathrm{OH}-\mathrm{DOC}$ output. In separated capsule incubations, $18-\mathrm{OH}-\mathrm{DOC}$ released into the medium was always $<3 \mathrm{pmol} / \mathrm{gland}$, and showed no consistent changes with treatments (data not shown).

In bisected glands which were divided after incubation into fasciculata/recticularis and glomerulosa fractions, analysis of $18-\mathrm{OH}-\mathrm{DOC}$ by direct (non-extracted) RIA of tissue homogenates showed that larger amounts were invariably stored within the tissue than released into the incubation medium. The tissue values suggest responses to captopril and angiotensin II similar to those seen in the incubation media of bisected glands. This is particularly clear in the glomerulosa fraction of the gland (Fig. 2b), in which angiotensin II, in the absence of captopril, caused a modest but significant increase in $18-\mathrm{OH}-\mathrm{DOC}$ content. Captopril too, in the absence of angiotensin, increased 18-OH-DOC content, but this was first reduced by a low concentration of angiotensin II, then restored by a higher concentration. Furthermore, while the values are significantly higher in the fasciculata/reticularis than in glomerulosa (Fig. 2c), these treatments had comparable effects on inner zone tissue 18-OH-DOC (t-18-OH-DOC) as well. Thus angiotensin II stimulated $18-\mathrm{OH}-\mathrm{DOC}$ in the absence of captopril, while captopril stimulated $18-\mathrm{OH}-$ DOC in the absence of angiotensin II (though as fractions of the total steroid these changes were lower than in glomerulosa tissue or incubation media). As in the other samples, the captopril-enhanced t-18-OH-DOC was reduced by the addition of angiotensin II.

\section{Corticosterone}

The results show that corticosterone outputs were very variable, and although this steroid was present in greatest amounts in the incubation media, none of the treatments with captopril or with angiotensin II produced statistically significant changes, except that capsular corticosterone output was enhanced by $100 \mathrm{nmol} / \mathrm{l}$ angiotensin II in the captopril-incubated group (Fig. $3 a$ and $b$ ).

\section{Immunocytochemistry}

Since only $18-\mathrm{OH}-\mathrm{DOC}$ is retained in the tissue in significant amounts, it is assumed that the immunocytochemistry shown in Fig. 4 reflects the distribution of this steroid, and is not due to crossreactivity with other steroids. The examples shown here are representative of three similar experiments. Immunocytochemistry using tissue taken from freshly killed animals shows a general distribution of 18-OH-DOC throughout the gland (Vinson et al. 1995b). However, after $20 \mathrm{~min}$ perfusion without stimulation $18-\mathrm{OH}-\mathrm{DOC}$ is retained only in the glomerulosa, with only a sparse reaction in the fasciculata/ reticularis. Stimulation with a bolus dose of 1 pmol angiotensin II caused a marked redistribution of the immunoactive steroid in the glomerulosa, and after 20-40 min, there appears to be a net loss of the steroid except in isolated islands of cells (Fig. 4). This treatment increased the secretion of aldosterone into the perfusion medium by $362 \pm 35 \% \quad(n=9)$. Control sections treated with non-immune sheep serum gave no reaction (not shown).

\section{Discussion}

In view of the prominence of the tissue RAS in the zona glomerulosa of the rat adrenal (Dzau et al. 1987, Mulrow 

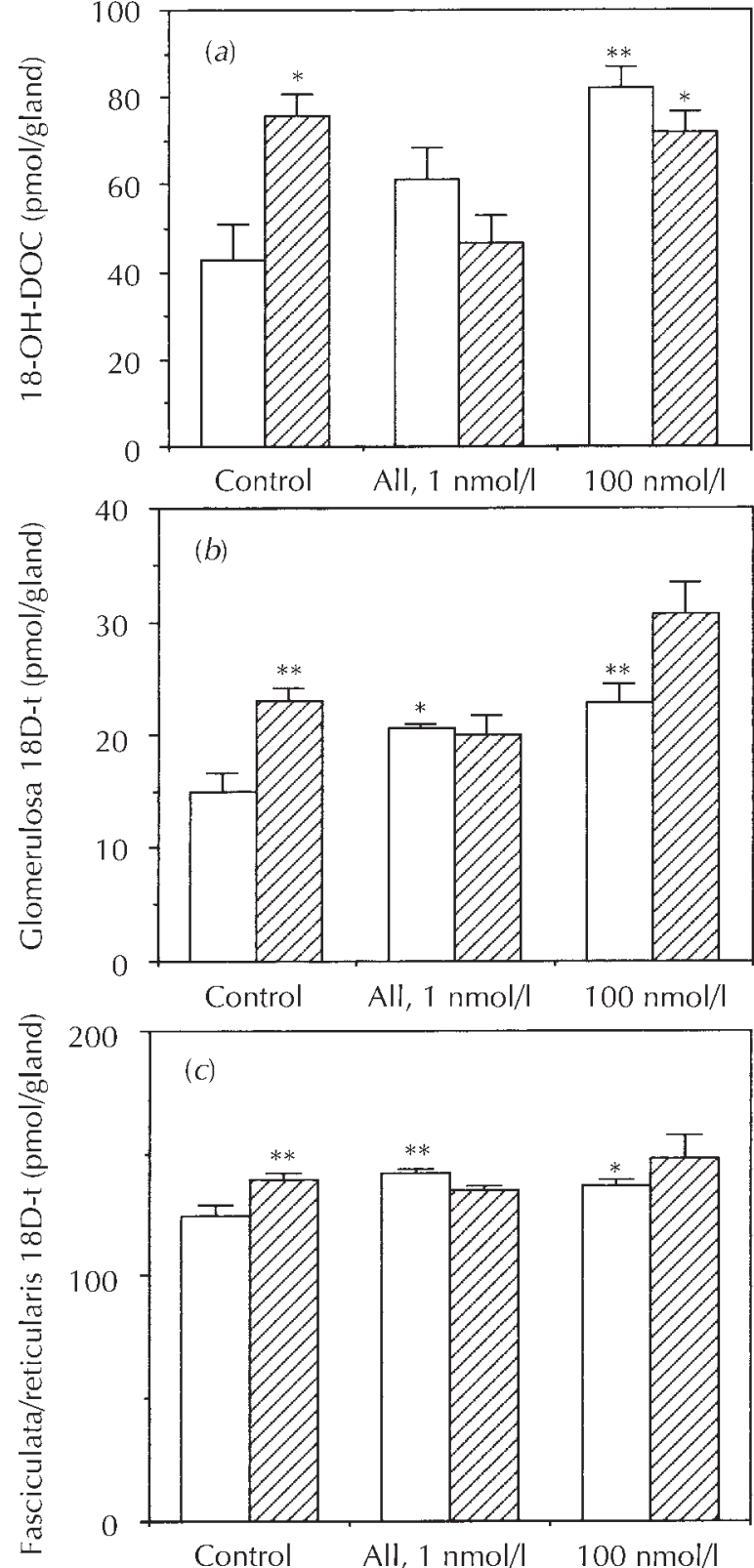

Figure 2 Effects of captopril (shaded bars), in the absence or presence of angiotensin II (AII) at two concentrations. (a) 18-OH-DOC output by bisected rat adrenal glands. t-18-OH-DOC content (18D-t) in (b) glomerulosa tissue or (c) fasciculata/ reticularis tissue obtained after incubation. Captopril gave increased 18-OH-DOC output under basal conditions (a), this was reduced to control values by a low concentration of angiotensin II, but enhanced again by a higher concentration. Tissue content of $18-\mathrm{OH}-\mathrm{DOC}$ in (b) glomerulosa and (c) fasciculata/reticularis tissues after incubation showed significant changes relative to controls that reflected the changes in secreted values shown in (a), though the absolute values fell into different ranges. Mean values \pm S.E.M., $n=6$ for each group. ${ }^{*} P<0 \cdot 05,{ }^{*} P<0 \cdot 01$ relative to unstimulated controls in the absence of captopril, by ANOVA and Student's t-test.
1992, Vinson 1995), it is assumed that the actions of captopril reported here are attributable to ACE inhibition; other possibilities, for example inhibition of bradykinin metabolism cannot be excluded, though there is no evidence for this in the adrenal. In this light, the data presented here confirm that tissue ACE, and the tissue generation of angiotensin II, are important in modulating the synthesis and secretion of aldosterone in the rat adrenal cortex. However, the situation is complex, and suggests that angiotensin II may have more than one role in the integrated adrenal gland.

In bisected glands, in which all of the zones of the gland remain in contact, basal output of aldosterone (Fig. 1a), though higher than in isolated capsules (Fig. 1b), is also further stimulated by angiotensin II, showing that the tissue is here less than maximally stimulated by endogenous angiotensin II. However, the response to exogenous angiotensin II is inhibited by captopril.

Conversely, in separated capsular glands, consisting of the connective tissue capsule in contact with the intact glomerulosa, captopril significantly reduces basal levels of aldosterone output (Fig. 1b). This suggests that in this preparation the glomerulosa is normally chronically stimulated by tissue-generated angiotensin II. The concept is supported by the further finding that under these conditions of incubation addition of exogenous angiotensin II stimulates aldosterone only when ACE activity is suppressed by captopril.

Clearly, the two tissue preparations reveal two different effects of captopril, and, presumably, two modes of angiotensin II action. Furthermore, in the whole tissue preparation, the fasciculata/reticularis must be involved. Steroidogenesis in the adrenal is exclusively linked to the AT1 receptor subtype (Balla et al. 1991), and recent data confirm that rat fasciculata cells contain AT1 receptors, though not, seemingly, linked to inositol trisphosphate action (Roskelley et al. 1992). Two types of 11ßhydroxylase, CYP11B1 and CYP11B3, both of which catalyse the production of corticosterone and $18-\mathrm{OH}-$ DOC, but neither of which catalyses the formation of aldosterone, are specifically expressed in the fasciculata/ reticularis of the rat adrenal (Mellon et al. 1995, Zhou et al. 1995). In contrast, aldosterone synthase (CYP11B2), which does not allow the accumulation of 18-OH-DOC (Nonaka \& Okamoto 1991, Okamoto \& Nonaka 1992), is confined to the zona glomerulosa (Ogishima et al. 1992, Ho \& Vinson 1993). Hence the action of any stimulant, or inhibitor, on 18-OH-DOC output is in fact an effect on an inner adrenal zone product. One way in which the interaction between different tissue zones can take place is that the inner zones provide substrate to the glomerulosa aldosterone synthase (Vinson et al. 1995b), explaining the enhanced output of aldosterone in the bisected glands compared with the capsules incubated in isolation. Captopril may therefore have an action in bisected glands that is not seen in the capsular gland, either possibly through 

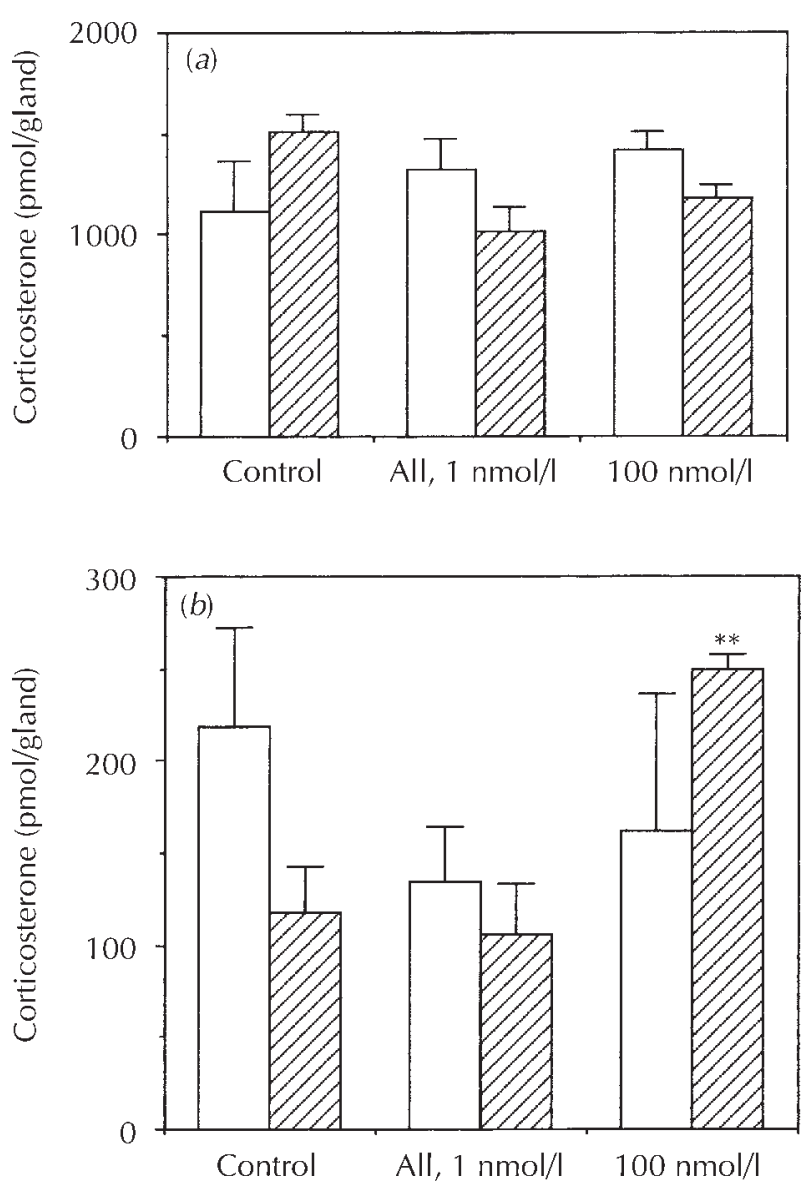

Figure 3 There were no significant differences in corticosterone output by (a) bisected glands in the captopril (shaded bars) and angiotensin II (AII) treatments. Corticosterone output by capsular glands (b) was extremely variable, and was generally not significantly affected by captopril or angiotensin, except that in the presence of captopril a high concentration of All stimulated corticosterone output relative to unstimulated control values in the presence of captopril ( $\left.{ }^{* *} P<0 \cdot 01\right)$. Mean values \pm S.E.M., $n=6$ for each group.

interrupting this flow of substrate between the zones, or in other ways making it unavailable to aldosterone synthase.

The hypothesis receives support from the present 18$\mathrm{OH}-\mathrm{DOC}$ data. In bisected glands, both the $18-\mathrm{OH}-$ DOC released into the incubation media, and that retained in the tissues, are enhanced by captopril (Fig. 2). There are two possible explanations: either captopril stimulates $18-\mathrm{OH}-\mathrm{DOC}$ production directly, or else it prevents its conversion to another product, perhaps by interrupting its distribution to the glomerulosa. No mechanism suggests itself for the stimulation of steroid output by captopril. However, either or both of the other two mechanisms are plausible, since captopril, while enhancing 18-OH-DOC, also inhibits the response of aldosterone output to exogenous angiotensin II. Since (in the absence of captopril) 18-OH-DOC is increased by angiotensin II
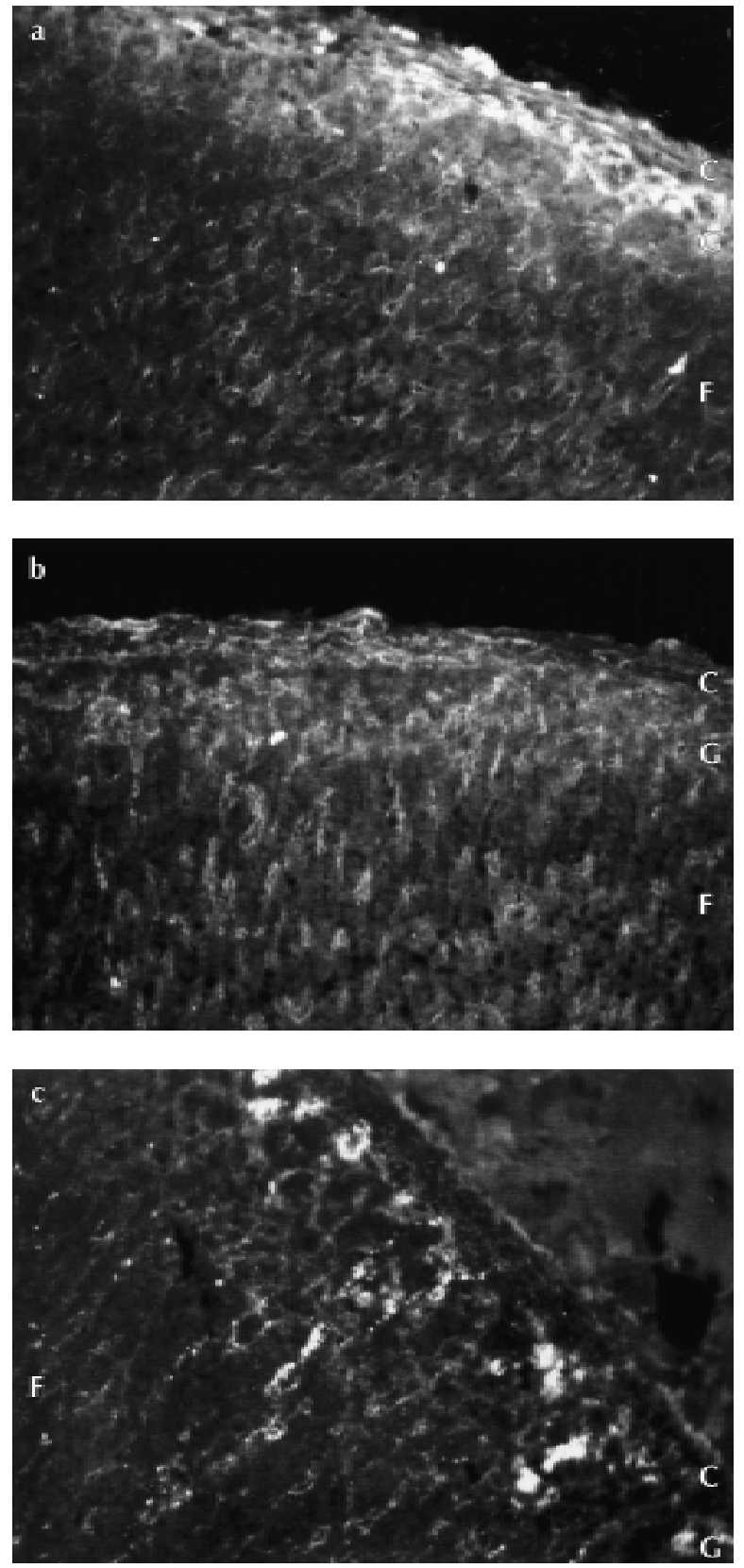

Figure 4 Immunolocalisation of $18-\mathrm{OH}-\mathrm{DOC}$ in rat adrenals after perfusion. (a) In control (unstimulated) conditions, 18-OH-DOC is diffusely located in the glomerulosa, and some is also seen in the membranes of fasciculata cells. (b) Five minutes after 1 pmol angiotensin II, less 18-OH-DOC is intracellular, and more is membrane located. Probably the $18-\mathrm{OH}$-DOC content is lower overall. (c) Twenty minutes after angiotensin II, intense staining is seen in only a few glomerulosa cells. $\mathrm{F}=$ fasciculata,

$\mathrm{G}=$ glomerulosa, $\mathrm{C}=$ capsule $\times 200$.

in incubation media, and in both glomerulosa and fasciculata/reticularis tissue in a manner that parallels the increased synthesis and release of aldosterone, the data 
support the view that $18-\mathrm{OH}-\mathrm{DOC}$ produced in the fasciculata/reticularis is a substrate for aldosterone formation by the glomerulosa (Vinson et al. 1995b). In contrast, the data for corticosterone convey no particular relationship with aldosterone synthesis (Fig. 3).

How may 18-OH-DOC be conveyed from inner adrenocortical cells to the glomerulosa, against the direction of blood flow through the gland? Furthermore, how could the suppression of tissue angiotensin output by captopril block the conversion of 18-OH-DOC to aldosterone? The answer to both of these problems may lie in our further observations of the effects of tissue disruption. We have previously shown that cell-cell contact contributes critically to the efficient synthesis of aldosterone in the rat adrenal cortex. Disruption of this contact by enzymic dispersal increases 18-OH-DOC output, and reduces aldosterone, in a manner highly reminiscent of the action of captopril in the present experiments (Vinson et al. 1985, 1991). One plausible role of tissue angiotensin therefore is to maintain such cell-cell contact, and possibly 18-OH-DOC transport through such direct contact.

The importance of $\mathrm{t}-18-\mathrm{OH}-\mathrm{DOC}$ in the response to angiotensin II is emphasised by the immunocytochemical results (Fig. 4). We have shown in previous studies that the distribution of $\mathrm{t}-18-\mathrm{OH}-\mathrm{DOC}$ is affected by physiological demand for aldosterone. In particular a variable pool of $\mathrm{t}-18-\mathrm{OH}-\mathrm{DOC}$ in the glomerulosa is enhanced by sodium depletion, and diminished by the specific release of aldosterone and 18-hydroxycorticosterone brought about by trypsin. Much of this pool is membrane associated (Vinson et al. 1995b). Under control conditions, Fig. 4a shows that in the intact perfused gland, $18-\mathrm{OH}-\mathrm{DOC}$ is located in the glomerulosa, and the changes in its distribution are consistent with the hypothesis that it is mobilised or utilised by angiotensin II stimulation. Though variably present in the glomerulosa in this way, the glomerulosa itself is not the source of $\mathrm{t}-18-\mathrm{OH}-\mathrm{DOC}$, since aldosterone synthase produces negligible yields of this steroid. Both of the fasciculata/reticularis species of $11 \beta$-hydroxylase do produce 18-OH-DOC, and indeed CYP11B3 gives greater yields of 18-OH-DOC than of corticosterone (Zhou et al. 1995). The fact that this P450 is regulated independently from CYP11B2 strongly suggests it has a specific role, which may lie in the generation of $\mathrm{t}-18-\mathrm{OH}-\mathrm{DOC}$ as an aldosterone substrate. It is particularly interesting that CYP11B3, like aldosterone synthase, is decreased by adrenocorticotrophin (Mellon et al. 1995).

\section{References}

Balla T, Baukal AJ, Eng S \& Catt KJ 1991 Angiotensin II receptor subtypes and biological responses in the adrenal cortex and medulla. Molecular Pharmacology 40 401-406.

Dzau VJ, Ellison KE, Brody T, Ingelfinger J \& Pratt RE 1987 A comparative study of the distributions of renin and angiotensin messenger ribonucleic acids in rat and mouse. Endocrinology $\mathbf{1 2 0}$ 2334-2338.
Fattah DI, Whitehouse BJ \& Vinson GP 1977 Biosynthesis of aldosterone from 18-hydroxylated precursors by rat adrenal tissue in vitro. Journal of Endocrinology 75 187-195.

Ferrario CM 1990 The renin-angiotensin system: importance in physiology and pharmacology. Journal of Cardiovascular Pharmacology 15 (Suppl 3) S1-S5.

Gupta P, Francosaenz R \& Mulrow PJ 1995 Locally generated angiotensin-II in the adrenal gland regulates basal, corticotropinstimulated, and potassium-stimulated aldosterone secretion. Hypertension 25 443-448.

Henville KL, Hinson JP, Vinson GP \& Laird SM 1989 Actions of desacetyl- $\alpha$-melanocyte-stimulating hormone on human adrenal cells. Journal of Endocrinology 121 579-583.

Hinson JP, Vinson GP, Whitehouse BJ \& Price GM 1985 Control of zona glomerulosa function in the isolated perfused rat adrenal gland in situ. Journal of Endocrinology 104 387-395.

Hinson JP, Vinson GP \& Whitehouse BJ 1988 Effects of dietary sodium restriction on peptide stimulation of aldosterone secretion by the isolated perfused rat adrenal gland in situ: a report of exceptional sensitivity to angiotensin II amide. Journal of Endocrinology 119 $83-88$.

Ho MM \& Vinson GP 1993 11ß-Hydroxylase gene expression in the rat adrenal cortex. Journal of Endocrinology 139 306-310.

Jeunemaitre X, Soubrier F, Kotelevtsev YV, Lifton RP, Williams CS, Hopkins PN, Williams RR, Lalouel J-M \& Corvol P 1992 Molecular basis of human hypertension: role of angiotensinogen. Cell 71 169-180.

Kifor I, Moore TJ, Fallo F, Sperling E, Menachery A, Chiou CY \& Williams GH 1991 The effect of sodium intake on angiotensin content of the rat adrenal gland. Endocrinology 128 $1277-1284$.

Mellon SH, Bair SR \& Monis H 1995 P450c11B3 mRNA, transcribed from a third $\mathrm{P} 450 \mathrm{c} 11$ gene, is expressed in a tissue-specific, developmentally, and hormonally regulated fashion in the rodent adrenal and encodes a protein with both 11-hydroxylase and 18-hydroxylase activities. Journal of Biological Chemistry 270 1643-1649.

Mulrow PJ 1992 Adrenal renin: regulation and function. Frontiers of Neuroendocrinology 13 47-60.

Nakamaru M, Misono KS, Naruse M, Workman RJ \& Inagami T 1985 A role for the adrenal renin-angiotensin system in the regulation of potassium-stimulated aldosterone production. Endocrinology 117 1772-1778.

Nonaka Y \& Okamoto M 1991 Functional expression of the cDNAs encoding rat $11-\beta$-hydroxylase $[\mathrm{p} 450(11-\beta)]$ and aldosterone synthase [p450(11- $\beta$, aldo)]. European Journal of Biochemistry 202 897-902.

Oda H, Lotshaw DP, Franco Saenz R \& Mulrow PJ 1991 Local generation of angiotensin II as a mechanism of aldosterone secretion in rat adrenal capsules. Proceedings of the Society for Experimental Biology and Medicine 196 175-177.

Ogishima T, Suzuki H, Hata J-I, Mitani F \& Ishimura Y 1992 Zone specific expression of aldosterone synthase cytochrome P-450 and cytochrome P-45011 $\beta$ in rat adrenal cortex: histochemical basis for the functional zonation. Endocrinology 130 2971-2977.

Okamoto M \& Nonaka Y 1992 Molecular biology of rat steroid $11-\beta$-hydroxylase $[\mathrm{p} 450(11-\beta)]$ and aldosterone synthase [p450(11- $\beta$, aldo)]. Journal of Steroid Biochemistry and Molecular Biology 41 415-419.

Peach MT 1977 Renin-angiotensin system: biochemistry and mechanism of action. Physiological Reviews 57 313-370.

Phillips MI, Speakman EA \& Kimura B 1993 Levels of angiotensin and molecular biology of the tissue renin angiotensin systems. Regulatory Peptides 43 1-20.

Roskelley CD, Baimbridge KG, Leung PCK \& Auersperg N 1992 Divergent differentiation of rat adrenocortical cells is associated with 
an interruption of angiotensin II-mediated signal transduction. Molecular and Cellular Endocrinology $8979-89$.

Sander M, Ganten D \& Mellon SH 1994 Role of adrenal renin in the regulation of adrenal steroidogenesis by corticotropin. Proceedings of the National Academy of Sciences of the USA 91 148-152.

Shier DN, Kusano E, Stoner GD, Franco Saenz R \& Mulrow PJ 1989 Production of renin, angiotensin II, and aldosterone by adrenal explant cultures: response to potassium and converting enzyme inhibition. Endocrinology 125 486-491.

Vazir H, Whitehouse BJ, Vinson GP \& McCredie E 1981 Effects of prolonged ACTH treatment on adrenal steroidogenesis and blood pressure in rats. Acta Endocrinologica 97 533-542.

Vinson GP 1995 The adrenal renin/angiotensin system. Advances in Experimental Medicine and Biology 377 237-251.

Vinson GP, Hinson JP \& Raven PW 1985 The relationship between tissue preparation and function; methods for the study of control of aldosterone secretion; a review. Cell Biochemistry and Function 3 235-253.

Vinson GP, Laird SM, Whitehouse BJ, Teja R \& Hinson JP 1991 The biosynthesis of aldosterone. Journal of Steroid Biochemistry and Molecular Biology 39 851-858.
Vinson GP, Ho MM \& Puddefoot JR 1995a The distribution of angiotensin II type 1 receptors, and the tissue renin-angiotensin systems. Molecular Medicine Today 1 35-39.

Vinson GP, Teja R, Ho MM \& Puddefoot JR 1995b A two cell type theory for aldosterone biosynthesis: the roles of $11 \beta$-hydroxylase and aldosterone synthase, and a high capacity, tightly binding steroid carrier (TBSC) for 18-hydroxydeoxycorticosterone. Journal of Endocrinology 144 359-368.

Wang Y, Yamaguchi T, Francosaenz R \& Mulrow PJ 1992 Regulation of renin gene-expression in rat adrenal zona glomerulosa cells. Hypertension 20 776-781.

Zhou M-Y, Gomez-Sanchez EP, Foecking MF \& Gomez-Sanchez CE 1995 Cloning and expression of the rat adrenal cytochrome P-450 11B3 (CYP11B3) enzyme cDNA: preferential 18 -hydroxylation over $11 \beta$-hydroxylation of DOC. Molecular and Cellular Endocrinology 114 137-145.

Received 4 August 1997

Revised manuscript received 19 December 1997 Accepted 10 March 1998 